\title{
Social representation of reproductive biotechnologies among nurses working in sexual and reproductive health
}

\author{
Representação social das biotecnologias reprodutivas entre enfermeiros que atuam na saúde sexual e reprodutiva
}

Representación social de biotecnologías reproductivas entre enfermeras que trabajan en salud sexual y reproductiva

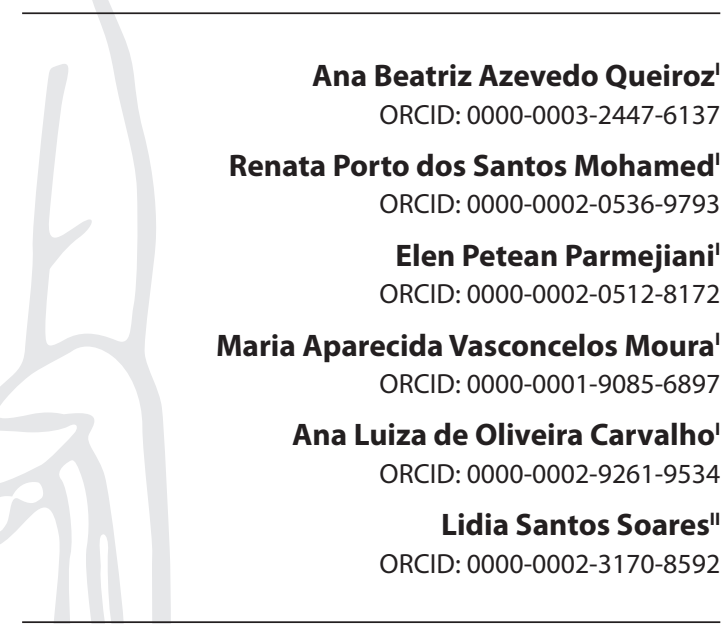

'Universidade Federal do Rio de Janeiro. Rio de Janeiro, Rio de Janeiro, Brazil.

"Universidade Federal Fluminense. Rio das Ostras, Rio de Janeiro, Brazil.

How to cite this article: Queiroz ABA, Mohamed RPS, Parmejiani EP, Moura MAV, Carvalho ALO, Soares LS. Social representation of reproductive biotechnologies among nurses working in sexual and reproductive health.

Rev Bras Enferm. 2021;74(1):e20200558. doi: http://dx.doi.org/10.1590/0034-7167-2020-0558

Corresponding author:

Ana Beatriz Azevedo Queiroz

E-mail: abaqueiroz@hotmail.com

EDITOR IN CHIEF: Antonio José de Almeida Filho ASSOCIATE EDITOR: Ana Fátima Fernandes

Submission: 06-24-2020

Approval: 09-17-2020

\begin{abstract}
Objectives: to compare the social representations of reproductive biotechnologies among sexual and reproductive health nurses, and their links with professional practice. Methods: an analytical, comparative, qualitative research, supported by the Theory of Social Representation, carried out in May/2014-February/2015, with 32 nurses from the city of Rio de Janeiro. Semistructured interview, analyzed by ALCESTE ${ }^{\circ}$ software. Results: nurses not active in assisted human reproduction represent reproductive biotechnologies as unnatural methods of human reproduction, assessing the practice in this field as generalist and bureaucratic. Those who work represent as auxiliary and supporting nature for heterosexual couples, considering the innovative and specialized practice. Final Considerations: each group presented specific contents and dimensions about reproductive biotechnologies. The representations are centered on moral, normative and ideological personal values, anchored in the traditional conceptions of human and family reproduction, but also collective, acquired in the professional routine, showing group identity and its distinct practices considering reproductive biotechnologies. Descriptors: Reproductive Health; Reproductive Techniques, Assisted; Professional Practice; Nursing; Psychology, Social.
\end{abstract}

\section{RESUMO}

Objetivos: comparar as representações sociais das biotecnologias reprodutivas entre enfermeiros que atuam na saúde sexual e reprodutiva, e seus nexos com a prática profissional. Métodos: pesquisa analítica, comparativa, qualitativa, amparada pela Teoria da Representação Social, realizada em maio/2014-fevereiro/2015, com 32 enfermeiros do município do Rio de Janeiro. Entrevista semiestruturada, analisada pelo software ALCESTE ${ }^{\circ}$. Resultados: enfermeiros não atuantes na reprodução humana assistida representam biotecnologias reprodutivas como métodos antinaturais de reprodução humana avaliando a prática nesta área como generalista e burocrática. Os que atuam representam como auxiliares e coadjuvantes da natureza para casais heterossexuais, considerando a prática inovadora e especializada. Considerações Finais: cada grupo apresentou conteúdos e dimensões específicas sobre biotecnologias reprodutivas. As representações estão centradas em valores pessoais de caráter moral, normativos e ideológicos, ancorados nas concepções tradicionais de reprodução humana e família, mas também coletivos, adquiridos no cotidiano profissional, evidenciando identidade grupal e suas distintas práticas diante das biotecnologias reprodutivas.

Descritores: Saúde Reprodutiva; Tecnologia Reprodutiva Assistida; Prática Profissional Enfermagem; Psicologia Social.

\section{RESUMEN}

Objetivos: comparar las representaciones sociales de las biotecnologías reproductivas entre enfermeras que trabajan en salud sexual y reproductiva y sus vínculos con la práctica profesional. Métodos: investigación analítica, comparativa, cualitativa, sustentada en la Teoría de la Representación Social, realizada en mayo/2014-febrero/2015, con 32 enfermeras de la ciudad de Rio de Janeiro. Entrevista semiestructurada, analizada por el software ALCESTE ${ }^{\circ}$. Resultados: las enfermeras no activas en reproducción humana asistida representan las biotecnologías reproductivas como métodos antinaturales de reproducción humana, evaluando la práctica en esta área como generalista y burocrática. Quienes laboran representan como auxiliares y ayudantes de la naturaleza para parejas heterosexuales, considerando la práctica innovadora y especializada. Consideraciones Finales: cada grupo presentó contenidos y dimensiones específicas sobre biotecnologías reproductivas. Las representaciones se centran en valores personales morales, normativos e ideológicos, anclados en las concepciones tradicionales de reproducción humana y familiar, pero también colectivas, adquiridas en la rutina profesional, mostrando la identidad grupal y sus prácticas diferenciadas ante las biotecnologías reproductivas.

Descriptores: Salud Reproductiva; Técnicas Reproductivas Asistidas; Práctica Profesional; Enfermería; Psicología Social. 


\section{INTRODUCTION}

Reproductive biotechnologies in humans were marked in the 70s, with the birth of Louise Brown, conceived through in vitro fertilization, one of the techniques of assisted human reproduction (AHR).This situation brought great repercussions to national and international society, definitively changing the representation of human reproduction. In Brazil, reproductive biotechnology had its mark in the 80 's, with the birth of the first test tube baby, when it spread in the country ${ }^{(1)}$.

Considered a biomedical term that describes a heterogeneous set of techniques around an initial axis of treatment for difficulty in gestating, AHR is expanding to other cases as an alternative for obtaining pregnancy in homoaffective couples, serodiscordants for the human immunodeficiency virus (HIV), singles, among others ${ }^{(2-3)}$.

This type of reproduction is a reality that has been expanding in the sphere of private health services, and is still incipient in Brazilian public services. In this context, nurses have been approaching this field, either due to job market demands or the need to expand human resources in this specific field ${ }^{(4)}$.

The progress of technological interventions in the process of human procreation requires greater training of professionals for skills in different fields of this knowledge, due to the bioethical, social and religious implications ${ }^{(5-6)}$. In this idea, it is observed that conversations, concerns, opinions and decision-making about reproductive biotechnologies are raised by sexual and reproductive health (SRH) nurses, which, in turn, influence professional practice to that kind of reproduction ${ }^{(7)}$.

In this set of ideas, reproductive biotechnologies, on a representative level, would have elements that would allow a connection with consensual and socially determined aspects in their constitution. It is essential to consider the way in which reproductive biotechnologies become an object of interest for SRH nurses, being able to develop specific assistance in the fields of reproduction, gender, sexuality, women's health, among others, that contemplate sexual and reproductive rights.

The current expansion of AHR, represented by the reproductive biotechnologies associated with biological children' demands, is close to the daily lives of SRH nurses with women and couples, in the settings of primary or specialized care. Usually, these professionals develop their assistance in maternity hospitals during the puerperal pregnancy cycle, in prenatal care, in gynecological nursing consultations, in reproductive planning, in the prevention and fight against violence against women, and, in recent years, with direct action to reproductive biotechnologies in AHR. Considering the above, it was empirically possible to perceive a diversity of production of meanings from the reproductive biotechnologies of the segment of these nurses who work with AHR and those who work in other SRH settings, who end up directing their attitudes and practices in the face of these technologies.

The study of the social representations of reproductive biotechnologies among SRH nurses will allow to know the symbolic configuration of the phenomenon and the ways in which different groups of nurses in this field see and think these biotechnologies, in an individual and collective perspective. Social representation translates the group's relationship with an object socially valued for its reach, especially to the extent that it differentiates one group from the other, either by its orientation, presence or absence in the field ${ }^{(8)}$.

In this context, considering that the approximation or distancing of reproductive biotechnologies can lead to the circulation of different information and practices, some questions arose, which generated guiding questions for this study: how do SRH nurses represent reproductive biotechnologies? Are there any differences in the social representations of nurses in this field due to their direct role or not with reproductive biotechnologies?

Evidencing how different SRH nurses elaborate representations about reproductive biotechnologies is essential considering that this understanding is directly linked to their professional practice in this field. The information and contents of the biotechnological revolution are subject to a new meaning on the part of nurses, who confront personal values with those acquired in the professional routine, forming a diversity of production of meanings in the face of this type of reproduction. This diversity deserves to be investigated considering the Theory of Social Representations (TSR) as knowledge about an object that has a strong connection with subjects' practices $^{(8)}$.

This approach becomes essential, since the first National Nursing Committee of the Brazilian Society for Human Reproduction was recently formed. This has the function of preparing an editorial relevant to the professional field, providing support to human resources, promoting continuing education, consultancy related to legislation and protocols in specialized services in $\mathrm{AHR}^{(9)}$. Moreover, this study may point to directions that offer subsidies to these functions. Therefore, this research is relevant because it is based on strengthening the practice of AHR nurses and the possibility of disseminating knowledge in SRH. Such an attempt is justified, in the sense of allowing sexual and reproductive rights comprehensiveness in the face of the transformation of society, the social practice of nurses and the political alignment and social justice.

\section{OBJECTIVES}

To compare the social representations of reproductive biotechnologies among sexual and reproductive health nurses, and their links with professional practice.

\section{METHODS}

\section{Ethical aspects}

The ethical principles of research with human beings were respected in compliance with Resolution $466 / 2012^{(10)}$ of the Brazilian National Health Council (Conselho Nacional de Saúde). This research was approved by the Ethics Committee of Escola de Enfermagem Anna Nery and Instituto de Atenção à Saúde São Francisco de Assis. All participants had their autonomy preserved when they were invited face to face to participate in the research and received information about the procedures, spontaneously signing the Informed Consent Form. The participants' confidentiality, anonymity and private location of choice were ensured for the interviews, identified by the initials Int., Followed by the sequential number of occurrence of the interview, in ascending order (e.g., Int. 01, Int. 02). 


\section{Theoretical-methodological framework}

TSR was applied in its procedural approach. Through this theory, we sought to understand the references of SRH nurses' thoughts about reproductive biotechnologies through psychosocial elements, i.e., that expose a reality not visible due to aspirations, values, beliefs and attitudes, going through the subjectivity of the subjects and supporting the way they carry out their practices ${ }^{(8,11)}$.

\section{Type of study}

This is an analytical and comparative research, using the qualitative approach, developed according to COREQ precepts.

\section{Methodological procedures, study setting, and data source}

Participants were chosen for convenience, with the participation of $32 \mathrm{SRH}$ nurses working in the city of Rio de Janeiro, Brazil. This quantitative was established to the extent that the content of the social representations on reproductive biotechnologies was obtained, i.e., when data in quantity and intensity capable of encompassing its multiple dimensions were reached. They were a social group of representativeness for the studies of TSR acceptable to obtain a theoretically interpretable result, able to highlight the restricted number of nurses who work with $\mathrm{AHR}^{(12)}$.

Participants were divided into two groups of belonging: Group 1, with 16 nurses who do not work with AHR; Group 2, with 16 participants working in this field. For inclusion of these individuals, the minimum working time of one year was considered, and nurses on vacation or leave during the data production period were excluded.

This performance period was determined to be a reasonable period of professional experience, in which the possible participants had a deadline for involvement with issues related to $\mathrm{SRH}$ and practice in AHR for Group 2. Therefore, they were able to convert this experience of the field in the elaboration of social representations about reproductive biotechnologies.

Recruitment and data production took place between May 2014 and February 2015. The initial setting for selecting participants, from both groups, was a federal health institution of reference for $\mathrm{SRH}$, located in the city of Rio de Janeiro (Brazil), being one of the public services that offers assistance in low and medium complexity $\mathrm{AHR}^{(13)}$. Subsequently, with the objective of capturing the largest possible number of nurses working in this field, the snowball sampling technique was chosen, indicated for recruiting a highly specialized population and a small number of members ${ }^{(14)}$.

This technique allowed the non-random capture of new participants, including, also, those with performance in in vitro fertilization, considered of high complexity in AHR, which are few in the municipality of Rio de Janeiro. It should be noted that, even using the snowball sampling technique, there were difficulties in recruiting participants for this study, especially in the private network. In order to minimize this limitation, a prolonged period was used for this phase of the research, being possible to obtain a quantitative of representativeness for TSR studies ${ }^{(12)}$.

\section{Data collection and organization}

Data production contemplated individual interview in depth using a semi-structured instrument and seeking elements for the production of social representations. The instrument's pre-test was performed with three potential participants whose data were not included in the study results. The interviews lasted an average of twenty minutes, with MP3 recording, transcribed in full and returned to participants for comments or corrections. After approval of the transcript, with no changes or exclusions, the process began.

\section{Data analysis}

Data analysis occurred after the corpus was processed in Analyze Lexicale par Contexte d'un Ensemble de Segments de Texte (ALCESTE') software, version 2012, whose objective was to highlight the word classes that gave rationality to subjects' statements about the research topic of interest ${ }^{(15)}$. From the textual organization, there were successive divisions of the material observed through Descending Hierarchical Classification (DHC), which made it possible to identify the most evident oppositions between the words of the text and create conditions to extract the representative classes of each group of belonging. Triangulation occurred in order to contemplate DHC analysis, Ascending Hierarchical Classification $(\mathrm{AHC})$ and the content of the elementary context units (ECU) of the lexical class. This triangulation is essential in TSR studies to prove the validity of the results obtained ${ }^{(16)}$.

For each group, a corpus of analysis was built, processed separately in ALCESTE $^{\circ}$. The classes analyzed that deal with the multidimensionality of reproductive biotechnologies and the contents of nurses' practices within AHR were Classes 1 and 4 of Group 1, and Classes 2 and 3 of Group 2, supporting comparative analysis.

The classes were named:"Class 1 - Reproductive biotechnologies: unnatural methods of human reproduction" and "Class 4 - Nursing performance in relation to reproductive biotechnologies: generalist and bureaucratic", referring to Group 1; "Class 3 - Reproductive biotechnologies: auxiliary and supporting methods to human reproduction in situations of infertility" and "Class 2 - Nursing performance in relation to reproductive biotechnologies: specialized field", referring to Group 2, analyzed in the light of TSR.

\section{RESULTS}

The characterization of SRH nurses is essential to verify the context in which the thinking about reproductive biotechnologies is elaborated, as well as the contents processed by ALCESTE . These reveal the words that bring meaning to this object, and are presented below in Charts 1 and 2.

\section{DISCUSSION}

Analysis of the relationships established between the social representations of reproductive biotechnologies and the two groups belonging to SRH nurses suggest common elements, but also distinct representations, which influence the practice of these nurses. 
Chart 1 - Characterization of the two groups of sexual and reproductive health nurses in relation to reproductive biotechnologies

\begin{tabular}{|c|c|}
\hline $\begin{array}{c}\text { GROUP } 1 \text { - Sexual and } \\
\text { reproductive health nurses who } \\
\text { do not work in assisted human } \\
\text { reproduction }\end{array}$ & $\begin{array}{c}\text { GROUP } 2 \text { - Sexual and } \\
\text { reproductive health nurses } \\
\text { who work in assisted human } \\
\text { reproduction }\end{array}$ \\
\hline \multicolumn{2}{|l|}{ Participants' characterization } \\
\hline $\begin{array}{l}94 \% \text { female } \\
100 \% \text { heterosexual } \\
50 \% \text { between } 36 \text { and } 45 \text { years old } \\
63 \% \text { Catholic } \\
69 \% \text { married/common-law } \\
\text { marriage } \\
50 \% \text { with natural children } \\
60 \% \text { graduated for more than } 15 \\
\text { years } \\
63 \% \text { with lato sensu specialization in } \\
\text { SRH - obstetric nursing field }\end{array}$ & $\begin{array}{l}70 \% \text { female } \\
100 \% \text { heterosexual } \\
58 \% \text { between } 46 \text { and } 65 \text { years old } \\
79 \% \text { Catholic } \\
65 \% \text { married/common-law } \\
\text { marriage } \\
44 \% \text { with natural children } \\
72 \% \text { graduated for more than } 15 \\
\text { years } \\
72 \% \text { with lato sensu specialization } \\
\text { out of the field of SRH }\end{array}$ \\
\hline
\end{tabular}

Nota: SRH - sexual and reproductive health.

Chart 2 - Synthesis of the social representations of the two groups of nurses of sexual and reproductive health in relation to reproductive biotechnologies

\section{GROUP 1 - Sexual and reproductive health nurses who do not work in assisted human reproduction \\ GROUP 2 - Sexual and reproductive health nurses who work in assisted human reproduction}

\section{Description of ALCESTE content - DHC and AHC}

Class 1 - Reproductive biotechnologies: unnatural methods of human reproduction

\section{ECU (29\% of corpus 1)}

Most frequent lexicons: son, mother, father, genetics, family, natural, human reproduction, biotechnology, disturbance, religion, abnormal, unnatural.

ECU content: this issue of generating children through technologies is unnatural. Professionals are playing God. Human reproduction is something divine and something natural. Reproductive biotechnologies bring a lot of confusion in what we always think is natural. Reproducing for me is daddy, mommy, son and through sexual intercourse. (Int.08)

It is a disturbing situation. The right thing is to

have only one father and one mother. Look how complicated it is: a child comes out of a woman's belly, another one donates eggs and is raised by another. (Int.25)

AHC: child-parents-mother-father.

Class 4 - Nursing performance in relation to reproductive biotechnologies: generalist and bureaucratic

\section{ECU ( $21 \%$ of corpus 1$)$}

Most frequent lexicons: practice, welcome, equal, bureaucratic, guide, generalist, non-specialized. ECU content: nurses do not have a specific practice in assisted reproduction, it is not the competence of nurses to work with reproductive biotechnologies. I think that he is not even part of the team, at most he welcomes like any other sector and is more in the bureaucratic part, filling out documents and records. He's a common nurse, generalist, bureaucratic. (Int. 03)

AHC: nursing-care-equal, guide-normal-practice.
Class 3 - Reproductive biotechnologies: auxiliary and supporting methods to human reproduction in situations of infertility

\section{ECU (35\% of corpus 2)}

Most frequent lexicons: difficulty, son, solution, infertility, problem, dream, couple, possibility, help, path.

ECU content: after starting to work here, I see reproductive biotechnologies as an important help in the possibility of the couple, a man and a woman, to have the child they dream and desire. It is a way to solve the difficulty of getting pregnant, it is only an aid to the natural process that is human reproduction. (Int.26)

For homosexuals, single or who choose sex, IQ, I do not accept! I think about the future of children, about the upbringing that comes from two men or two women. Reproductive biotechnologies have a certain indication that it is when heterosexual couples find it difficult to conceive. Reproduction is a family institution that should not be changed. God's things must not change! (Int. 28)

AHC: technology-help, difficulty-problem-solving and solution-path-possibility.

Class 2 - Nursing performance in relation to reproductive biotechnologies: specialized field

\section{ECU (24\% of corpus 2)}

Most frequent lexicons: care, practice, different, nursing, field, specialized.

ECU content: the practice of nurses in assisted reproduction is different, specialized and innovative. It requires respect, acceptance, humanization to have quality care. It ends up being differentiated by the particularity of the clientele. I think it is an innovative field for nursing to work. (Int.34)

AHC: care-practice-different-nurse, competencehumanization-welcoming-expert. tween the internal and external worlds, subjects and collectivities, which the interviewees belong to between psychic structures and different realities ${ }^{(19)}$.

Although this representation of the naturalness of human reproduction is common in both groups studied, there is a greater frequency of this lexicon in Group 1. These nurses presented contents correlated to the biological parenting of human reproduction (Class 1), which may be correlated to the social context of this segment, which, in its great majority, are women, heterosexual, catholic, married, with children of natural conception. On the other hand, in the SRH field, they are experts in obstetric nursing, working in reproductive planning, prenatal care and obstetrics. That is, fields impregnated by the references of the comprehensiveness of the human being, humanization, de-medicalization of the body and the damage caused by the excessive use of manipulations and technologies for women's health, who have historically been attributed the competence for reproduction ${ }^{(20-21)}$.

The religious influence stands out in the statements, which tends to propitiate the ideology of tradition directed to the classic family formation, constituted by a heterosexual couple with children, whose reproduction occurs through the sexual act ${ }^{(22)}$, which can explain the objectification process of reproductive biotechnology as a disturbing and unnatural situation.

This representation accompanies the Catholic Church's position in relation to assisted reproduction, considering 
that reproductive biotechnologies separate procreation from sexual function, affecting the dignity of reproduction, which is considered a blessing and a divine gift ${ }^{(23)}$.

Given the conceptions and beliefs of reproduction and family socially constructed as untouchable ${ }^{(18)}$, reproductive biotechnologies mobilize these nurses' thoughts of strangeness in the face of new paradigms. This representation was elaborated considering the excessive manipulation of the bodies, children of same-sex couples, search for genetic-hereditary characteristics, donation of gametes and solidary belly as possible means to gestate in the context of AHR.

Human reproduction, based on the reified universe of sciences, anchored in the physiology of sexual intercourse, as in the content of the consensual and religious universe, brings the sense that professionals who work with AHR are "playing God". Everything that is not classified by the individual becomes strange and threatening, and, for this reason, the representation can be understood as a naming process, in which an imagination and assessment classification of a fact or phenomenon will be established, generating a judgment between positive and negative ${ }^{(8)}$. This chain of negative meanings leads Group 1 to assess that biotechnologies are not solutions to reproductive demands. This thinking can compromise performance at $\mathrm{SRH}$, not being in line with reproductive rights. Information provision, the means/ methods and techniques for having children are part of these rights and must be considered in reproductive assistance ${ }^{(1)}$.

Considering that social representations are organized through knowledge, meanings and context that guide subjects' practices ${ }^{(8)}$, one can understand the interpretation that Group 1 has of reproductive biotechnologies. It is justified for presenting the imagery dimension of AHR as an field based on medicalization and highcomplexity technical-medical procedures ${ }^{(13)}$. This fact seems to come in line with the current obstetric nursing perspective, which is the greatest training of these $\mathrm{SRH}$ nurses. In this case, they did not consider it to be a field of action for nurses, as if nursing were only prepared and able to deal with the phenomena of nature when referring to human reproduction.

Technological health interventions are strictly related to human conditions, and the diverse factors that influence it are associated with socioeconomic, cultural, psychosocial, affective, social issues, both at the individual and collective levels ${ }^{(24)}$. In this directive, Class 4 demonstrates that nurses in Group 1 consider that there is no specific role in relation to reproductive biotechnologies, their practice being essentially bureaucratic and generalist.

The general practice of nurses, with welcoming activities, guidelines and even administrative and bureaucratic actions, were the only practices understood as possible in this field. This finding was also found in a study carried out at the Technological Institute Dethessaloniki, in Greece, with 609 professionals and 234 students, about knowledge about AHR, indicating that they have little knowledge about reproductive biotechnologies and are unaware of the specificity of their professional role ${ }^{(25)}$.

In the comparative process, Group 2 presented contents that explain reproductive biotechnologies as just a technological aid, demonstrating that the symbolic value attributed is reduced to an auxiliary and supporting procedure of nature. Technologization is able to circumvent biological limits. These technological resources acquire the sense of reconstructing the natural (13), solving reproductive problems for couples living with infertility.

In this segment of nurses, the artificial was anchored in the perspective of the normal and the natural, which reinforces the ideology that technological intervention in AHR is only a facilitator of the reproduction course for the constitution of traditional families. In this line of reasoning, they understand the importance of reproductive biotechnologies in the face of technological assistance for human nature, representing being the future in the face of issues involving reproductive difficulties, mainly because of the relationship between the biological son of heterosexual couples. These exposed considerations give the sense that the alternative solutions for infertility must bring an intrinsic connotation of naturalness. This representation has a strong meaning in the daily work of this group, building a concrete, tangible and palpable image of the object under study.

In this different context, reproductive biotechnologies, for the group of nurses who work directly with AHR, are now elaborated as a solution to the issues surrounding reproductive difficulties based on scientific thinking, in the reified universe of science, belonging to a statement of experts ${ }^{(8)}$.

In view of this solo to represent and assist human reproduction, these technologies have specific indications, which should be limited to cases of infertility for heterosexuals, not being accepted to meet homo-affective, single or genetic manipulation demands, according to Class 3, although AHR is currently a strategy beyond the difficulty in gestating ${ }^{(2)}$. This concern of nurses in Group 2 was related to psychological and emotional conflicts that can occur in children in situations that are not very normative in society ${ }^{(26)}$.

These professionals' representations seem to move between contemporary conceptions and resistance to old reproductive paradigms, which may explain the paradox that places them between accommodation and resistance in accepting biotechnologies for homoaffective and single people. This fact can be understood by being a representation elaborated by a group of religious professionals, married, heterosexual and with biological children.

Reproductive biotechnologies were initially introduced to treat infertile heterosexual couples; therefore, their initiation outside the context of infertility in relation to the homoaffective population is a more recent practice and discussion ${ }^{(27)}$. This situation can also contribute to the position of non-acceptance of these professionals. The relevance of this finding affects the prescriptive function of social representation ${ }^{(8)}$, by denying the use of reproductive biotechnologies outside the infertility of heterosexual couples. The action guided by this representation tends to marginalize the reproductive rights of people outside this normativity.

Based on the logic that AHR is part of the future when it comes to human reproduction for couples with infertility, this segment, unlike the previous one, understands that reproductive biotechnology is a promising field of work for nurses, according to Class 2. These highlight the need to be highly specialized and differentiated professionals, since they must articulate technological knowledge, welcoming and ethics ${ }^{(7,18)}$. This inference may be based on some international research on the role of nurses in 
AHR, such as a study carried out in the United States (2018) on a new strategy that is being used by nurses in this field, which is Telenursing, used to communicate with patients on fertility and reproduction. The results reaffirm that these professionals who work with reproductive biotechnologies need to be differentiated, as they are required constant proximity to the couples who experience AHR, having the responsibility to care for, monitor and respond to the health demands and needs of these couples ${ }^{(28-29)}$.

In that vein, taking care of this clientele in a technological environment means to guide their care practice with competence, positions and actions, in addition to affectivity in interpersonal relationships through empathy, trust and respect for the demands of those who seek this type of service and care ${ }^{(18,30)}$.

\section{Study limitations}

The limitation of the research is the fact that it was developed in a single municipality in Rio de Janeiro, Brazil, and with a restriction on the number of professionals working in this field. Broader studies are needed requiring settings in diverse realities, in order to enable advances on the relationship between nurses' work from SRH and reproductive biotechnologies in caring for this specific clientele.

\section{Contributions to nursing, health, and public policies}

The research reveals the need to promote discussions and further research on reproductive biotechnologies to SRH nurses, managers, educational institutions and future nurses, in order to meet the demands related to sexual and reproductive rights. It also emphasizes the motivation to exercise the skills to practice in $\mathrm{AHR}$, considering it to be a new and challenging field of expertise for these professionals, with the expansion of new knowledge in the field of expertise.

\section{FINAL CONSIDERATIONS}

The contents and meanings of reproductive biotechnologies were evidenced by the two groups of nurses in the $\mathrm{SRH}$ field through socio-cognitive and affective dimensions of social representation. The results showed in an analytical interpretation that each group of belonging presents specific contents, dimensions and particularities about reproductive biotechnologies, making it clear that, for each segment, representation is centered on personal, but also collective values, with which they were acquired in the everyday professional.

In the context of conceptual transformation of human reproduction in contemporary times, resulting from new reproductive biotechnologies and the procreative demands of society, AHR nurses appear in line with the technological apparatus available. However, they precede the bond of procreation, the phenomenon of nature and its cultural dimensions of children and heterosexual couples. In contrast, the opposite group represents it as unnatural, causing disturbances and conflicts with traditional conceptions about reproduction. These different representations influence and guide the conceptions of professional practice in the face of reproductive biotechnologies, showing the group identity and its distinct practices in physical and social environments.

It is concluded that the social thought about the studied object shared by the two groups of belonging is impregnated by moral, normative and ideological elements, anchored in the traditional conceptions of human and family reproduction. The responses, associated with the senses and affections, are subject to the approximation or distancing in the daily work of these nursing professionals in the SRH field.

\section{REFERENCES}

1. Costa APCA. Reproductive rights, family planning and assisted human reproduction in Brazil in the current state of the art. Cad Ibero-Amer Dir Sanit. 2016;5(3):80-103. doi: 10.17566/ciads.v5i3.316

2. Choudhary KK, Kavya KM, Jerome A, Sharma RK. Advances in reproductive biotechnologies. Vet World. 2016;9(4):388-95. doi: 10.14202/ vetworld.2016.388-395

3. Inhorn MC, Patrizio P. Infertility around the globe: new thinking on gender, reproductive technologies and global movements in the $21 \mathrm{st}$ century. Hum Reprod Update. 2015;21(4):411-26. doi: 10.1093/humupd/dmv016

4. Leite PA, Moraes-Filho IM, Félis KC, Leite ACA, Leite-Jr PS, Guimarães CM. [The state of the art of nursing work on assisted reproduction]. Rev Inic Cient Ext [Internet]. 2018 [cited 2020 Mar 29];1(Esp 4):390-9. Available from: https://revistasfacesa.senaaires.com.br/index.php/ iniciacao-cientifica/article/view/126/84 Portuguese.

5. Garcia S, Belmy M. Assisted conception services and regulation within the Brazilian context. JBRA Assist Reprod. 2015;19(4):198-203. doi: 10.5935/1518-0557.20150039

6. Izzo CR, Monteleone PAA, Paulo C, Serafini PC. Human reproduction: current status. Rev Assoc Med Bras. 2015;61(6):557-9. doi: 10.1590/1806-9282.61.06.557

7. Queiroz ABA, Mohamed RPS, Moura MAV, Souza IEO, Carvalho MCMP, Vieira BDG. Nursing work in assisted human reproduction: between technology and humanization. Rev Bras Enferm. 2020;73(3):e20170919. doi: 10.1590/0034-7167-2017-0919

8. Moscovici S. Social representations investigations in social psychology. 11th. Petrópolis: Ed Vozes; 2017.

9. Sociedade Brasileira de Reprodução Humana-SBRH. News: nursing participates in the Brazilian society of human reproduction[Internet]. São Paulo: SBRH. 2017 [cited 2020 Mar 29]. Available from: https://www.sbrh.org.br/?p=1034

10. Ministério da Saúde (BR). Conselho Nacional de Saúde. Resolução CNS n 466, de 12 de dezembro de 2012. Aprova diretrizes e normas regulamentadoras de pesquisas envolvendo seres humanos. Diário Oficial da União. 2013 Jun 13. 
11. Jodelet D. [Psychosocial issues of the subject concept approach]. Cad Pesqui. 2015;45(156):315-27. doi: 10.1590/198053143203 French.

12. Silva SED, Camargo BV, Padilha MI. [The social representations theory in Brazilian nursing research]. Rev Bras Enferm. 2011;64(5):947-951. doi: 10.1590/S0034-71672011000500022 Portuguese.

13. Corrêa MCD, Loyola MA. [Assisted reproductive technologies in Brazil: options to improve access]. Physis (Rio J.). 2015;25(3):753-77. doi: 10.1590/S0103-73312015000300005 Portuguese.

14. Costa BRL. [Virtual Snowball: The use of social networks virtual processes in the data collection process of a scientific research]. Rigs [Internet]. 2018 [cited 2020 Mar 29];7(1):15-37. Available from: https://portalseer.ufba.br/index.php/rigs/article/viewFile/24649/16131 Portuguese.

15. Almeida RO, Oliveira FT, Ferreira MA, Silva, RC. Newly undergratuate nurse and intensive care in units of non-critical patients. Rev Bras Enferm. 2019;(Suppl 1):243-51. doi: 10.1590/0034-7167-2017-0713

16. Apostolidis T. [Social representations and triangulation: an application in social psychology of health]. Psicol Teor e Pesqui. 2006;22(2):21126. doi: 10.1590/S0102-37722006000200011. French.

17. Luna N. [Test-tube baby and clones: an anthropology of new reproductive technologies]. Rio de Janeiro: Fiocruz [Internet]. 2007 [cited 2020 Mar 29]. Available from: http://books.scielo.org/id/dqhw2/pdf/luna-9788575413555.pdf Portuguese.

18. Warmelink JC, Adema W, Pranger A, Cock TP. Client perspectives of midwifery care in the transition from subfertility to parenthood: a qualitative study in the Netherlands. J Psychosom Obstet Gynaecol. 2015;37(1):12-20. doi: 10.3109/0167482X.2015.1106474

19. Yaegashi SFR, Coutinho KA. [Nelson Rodrigues's os sete gatinhos: representations and inter-relationships]. Acta Sci. 2017;39(1):55-62. doi: 10.4025/actascihumansoc.v39i1.30543 Portuguese.

20. Pinheiro TF, Couto MT. [Sexuality and reproduction: discussing gender and integral care in Primary Health Care]. Physis (Rio J.). 2013;23(1):73-92, 2013. doi: 10.1590/S0103-73312013000100005. Portuguese.

21. Oliveira FAM, Leal GCG, Wolff LDG, Rabelo M, Poliquesi CB. Reflections on the nurse's role in the rede cegonha (stork network). Rev Enferm UFPE. 2016;10(Supl.2):867-74. doi: 10.5205/reuol.6884-59404-2-SM-1.1002sup201622

22. Crespo E, Bestard J. Psychosocial needs of women and their partners after successful assisted reproduction treatment in Barcelona. Reprod Biomed Soc. 2017;29;3:90-99. doi: 10.1016/j.rbms.2017.04.001

23. Sallam HN, Sallam NH. Religious aspects of assisted reproduction. Facts Views Vis Obgyn [Internet]. 2016 [cited 2020 Mar 29];8(1):33-48. Available from: https://www.ncbi.nlm.nih.gov/pmc/articles/PMC5096425/pdf/FVVinObGyn-8-33.pdf

24. Souza LEPF. Health, development and innovation: a contribution of the critical theory of technology to the discussion. Cad Saúde Pública. 2016;32(Suppl 2):e00029615. doi: 10.1590/0102-311X00029615

25. Papaharitou S, Nakopoulou E, Moraitou M, Hatzichristou D. Assisted reproduction and midwives: student and certified midwives educational needs on reproductive biology. Sex Reprod Healthc. 2010;1(4):163-8. doi: 10.1016/j.srhc.2010.07.002

26. Araldi MO, Serralta FB. A systematic review of same-sex parenthood. Psicol Pesqui: 2016;10(2):31-9. doi: 10.24879/201600100020057.

27. Haskova H, Zdenek S. Negotiating access to assisted reproduction technologies in a post-socialist heteronormative context. J Int Womens Stud [Internet]. 2018 [cited 2020 Mar 29];20(1), 53-67. Available from: https://vc.bridgew.edu/cgi/viewcontent.cgi?article=2088\&context=jiws

28. Johnson B, Quinlan MM, Marsh JS. Telenursing and nurse-patient communication within fertility, inc. J Holist Nurs. 2018;36(1):38-53. doi: $10.1177 / 0898010116685468$

29. Stevenson EL, Hershberger PE, Bergh PA. Evidence-based care for couples with infertility. J Obstet Gynecol Neonatal Nurs. 2016;45(1):10010. doi: 10.1016/j.jogn.2015.10.006

30. Silva RC, Ferreira MA, Apostolidis T, Brandão MAG. A conceptual framework of nursing care clinic in therapy intensive. Rev Latino-Am Enferm. 2015;23(5):837-45. doi: 10.1590/0104-1169.0501.2622 